OPEN ACCESS

Edited by:

Raffaele Badolato,

University of Brescia, Italy

Reviewed by:

Kohsuke Imai,

Tokyo Medical and Dental

University, Japan

Antonio Condino-Neto,

University of São Paulo, Brazil

*Correspondence:

Su Han Lum

s.lum@nhs.net

Specialty section: This article was submitted to

Pediatric Immunology,

a section of the journal

Frontiers in Pediatrics

Received: 11 July 2019 Accepted: 27 November 2019 Published: 11 December 2019

Citation:

Lum SH, Neven B, Slatter MA and Gennery AR (2019) Hematopoietic

Cell Transplantation for MHC Class II Deficiency. Front. Pediatr. 7:516. doi: 10.3389/fped.2019.00516

\section{Hematopoietic Cell Transplantation for MHC Class II Deficiency}

\author{
Su Han Lum ${ }^{1 *}$, Benedicte Neven 2,3,4, Mary A. Slatter ${ }^{1,5}$ and Andrew R. Gennery ${ }^{1,5}$ \\ on behalf of Inborn Errors of Working Party (IEWP) European Society for Blood \\ Marrow Transplantation (EBMT)
}

\footnotetext{
${ }^{1}$ Children's Haematopoietic Stem Cell Transplant Unit, Great North Children's Hospital, Newcastle upon Tyne Hospital NHS Foundation Trust, Newcastle upon Tyne, United Kingdom, ${ }^{2}$ Paris Descartes-Sorbonne Paris Cité University, Paris, France, ${ }^{3}$ Pediatric Hematology-Immunology and Rheumatology Unit, Necker-Enfants Malades Hospital, Assistance Publique-Hôpitaux de Paris (APHP), Paris, France, ${ }^{4}$ INSERM U1163 and Imagine Institute, Paris, France, ${ }^{5}$ Institute of Translational and Clinical Research, Newcastle University, Newcastle upon Tyne, United Kingdom
}

Major histocompatibility complex (MHC) class II deficiency is a rare and fatal primary combined immunodeficiency. It affects both marrow-derived cells and thymic epithelium, leading to impaired antigen presentation by antigen presenting cells and delayed and incomplete maturation of CD4+ lymphocyte populations. Affected children are susceptible to multiple infections by viruses, Pneumocystis jirovecii, bacteria and fungi. Immunological assessment usually shows severe CD4+ T-lymphocytopenia, hypogammaglobulinemia, and lack of antigen-specific antibody responses. The diagnosis is confirmed by absence of constitutive and inducible expression of $\mathrm{MHC}$ class II molecules on affected cell types which is the immunologic hallmark of the disease. Hematopoietic cell transplantation ( $\mathrm{HCT}$ ) is the only established curative therapy for $\mathrm{MHC}$ class II deficiency but it is difficult as affected children have significant comorbidities at the time of HCT. Optimization organ function, implementing a reduced toxicity conditioning regimen, improved T-cell depletion techniques using serotherapy and graft manipulation, vigilant infection surveillance, pre-emptive and aggressive therapy for infection and newer treatments for graft-versus-host disease have improved the transplant survival for children with MHC class II deficiency. Despite persistent low CD4+ T-lymphopenia reported in post-HCT patients, transplanted patients show normalization of antigenspecific T-lymphocyte stimulation and antibody production in response to immunization antigens. There is a need for a multi-center collaborative study to look at transplant survival of HCT and long-term disease outcome in children with MHC class II deficiency in the modern era of HCT.

Keywords: MHC class II deficiency, children, hematopoietic cell transplantation, transplant strategy, survival

\section{KEYPOINTS}

- MHC class II deficiency is a form of severe combined immunodeficiency-urgent referral should be made once the diagnosis is suspected.

- Severe and chronic viral infections are the hallmarks of the disease.

- The most prominent immunologic features are the absence or very low HLA-DR expression on lymphocytes, with reduced CD4+ T-lymphocyte counts leading to an inverted CD4/CD8 ratio. 
- Early diagnosis of MHC class II deficiency is important to enable prompt referral to a specialized center for hematopoietic cell transplantation before occurrence of end organ damage secondary to recurrent infection.

\section{INTRODUCTION}

Major histocompatibility complex (MHC) class II deficiency, also known as bare lymphocyte syndrome type II, is a rare autosomal recessive combined immunodeficiency and was first described in 1980s (1). MHC class II molecules are pivotal for the adaptive immune system and guide the development and function of CD4+ T-lymphocytes. The immunologic hallmark of the disease is the absence of constitutive and inducible expression of MHC class II molecules on all cell types which leads to impaired antigen presentation by HLA-DR, HLA-DQ, and HLA-DP molecules on antigen presenting cells (APC) (2). Besides affecting marrow-derived cells, the lack of MHC class II expression on thymic epithelium also leads to delayed and incomplete maturation of CD4+ T-lymphocytes. MHC class II-mediated peptide presentation is essential for positive and negative selection of the CD4+ T-lymphocyte population in thymus, and for the homeostasis of the mature CD4+ T-lymphocyte population in the periphery. Overall, MHC class II deficiency leads to combined immunodeficiency with defective CD4+ T-lymphocyte maturation and activation and a lack of $\mathrm{T}$ helper lymphocyte-dependent antibody production by $\mathrm{B}$ lymphocytes, resulting in significant susceptibility to severe infections and frequently death in early childhood (3). The reported incidence of $\mathrm{MHC}$ class II deficiency ranges from 5\% of SCID in Canada to $20-30 \%$ of SCID in Kuwait and in North Africans Countries $(4,5)$.

\section{MHC CLASS II DEFICIENCY AND GENETICS}

The MHC class II genes are located on chromosome 6 and transcription is tightly regulated according to a strict-cell-typespecific and quantitatively modulated pattern. Their expression is largely restricted to thymic epithelial cells and APC that are dendritic cells, macrophages and B-lymphocytes. In MHC class II deficiency, the MHC locus itself is intact in patients and it is a monogenic disease caused by mutations in the genes encoding for four regulatory factors controlling transcription of MHC class II genes. These regulatory factors are CIITA (class II transactivator), RFX5 (regulatory factor 5), RFXAP (RFXassociated protein), and RFXANK (RFX-associated ankyrincontaining protein) (Figure 1).

CIITA, which accounts for $15 \%$ of MHC class II deficiency, is an inducible factor that controls the expression of MHC class II gene expression by binding to the RFX complex and triggering transcription. The RFXANK, RFX5, and RFXAP proteins are subunits of the ubiquitously expressed RFX complex, which binds directly to the promoters of all MHC class II genes and together with other pleiotropic factors, forms the MHC class II expression enhanceosome (6). Over $85 \%$ of affected children have mutations in genes encoding for RFX complex and half of the reported cases have RFXANK deficiency.

\section{SPECTRUM OF DISEASE IN CHILDREN WITH MHC CLASS II DEFICIENCY}

Although MHC class II deficiency is not considered a classical severe combined immunodeficiency (SCID) according to the International Union of Immunological Societies (IUIS) classification criteria, patients usually present with a clinical phenotype that is very similar to SCID (7). Infectious susceptibility is broad toward viruses (e.g., cytomegalovirus, herpes simplex), bacteria (e.g., Staphylococcus sp., Streptococci sp., Pseudomonas sp., Salmonella sp.), fungi (e.g., Candida sp.), and protozoa (e.g., Pneumocystis jirovecii). These infections affect the gastrointestinal, pulmonary, respiratory tracts, beginning in the first year of life. Severe and chronic viral infections are the hallmarks of the disease and are associated with a poor prognosis. Recurrent bronchopulmonary infections caused by bacteria, viruses and Pneumocystis jirovecii are frequently observed. Older children may present with organ impairments such as chronic lung disease, chronic diarrhea with malabsorption and growth faltering. Intestinal and hepatic involvement caused by Crytosporidium colonization has been reported in patients with MHC class II deficiency; patients may develop chronic liver disease secondary to cryptosporidium infection. The absence of generalized BCGitis in these patients might in part be accounted for by the presence of residual immunity in the form of $\mathrm{CD}^{+}$T-lymphocytes and natural killer cells. Autoimmune

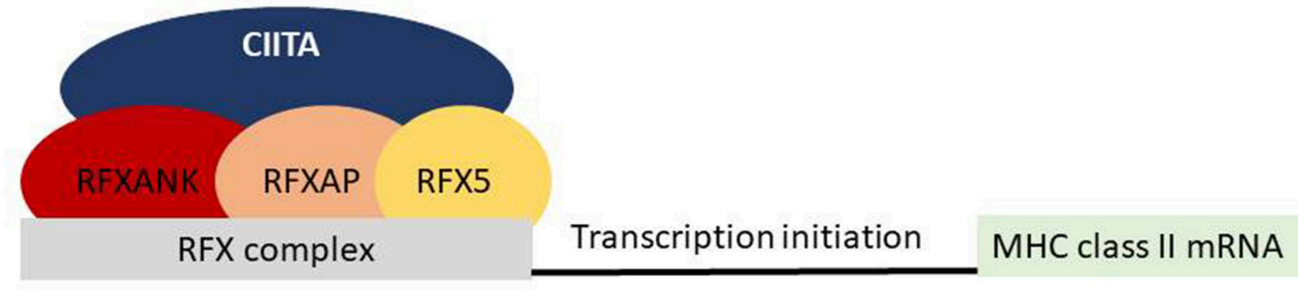

FIGURE 1 | Molecular defects in patients with MHC class I| deficiency. Four different transcription factors on MHC class I| promoters have been associated with MHC class II deficiency. 
manifestations such as autoimmune cytopenia have been observed in $20 \%$ of patients with MHC class II deficiency (8).

\section{DIAGNOSIS AND IMMUNOLOGIC FEATURES OF CHILDREN WITH MHC CLASS II DEFICIENCY}

Patients with MHC class II deficiency generally have severe CD4+ T-lymphocytopenia, hypogammaglobulinemia and lack of antigen-specific antibody responses. Proliferations to mitogen are usually conserved while absent to antigen. The hallmark finding on lymphocyte phenotypes is the absence or very low HLA-DR expression on lymphocytes, with decreased CD4+ T-lymphocyte counts leading to an inverted CD4/CD8 ratio (Figure 2). The CD4+ lymphocytopenia reflects the abnormal $\mathrm{CD} 4+$ thymocyte development, resulting from defective MHC class II expression in the thymus. CD8+ T-lymphocyte counts may be normal or low. T cell receptor excision circles (TREC) has been reported to be measurable in some affected patients and the diagnosis can be missed in TREC-based newborn screening for severe combined immunodeficiency (9-11).

\section{APPROACH TO HAEMATOPOIETIC CELL TRANSPLANTATION IN CHILDREN WITH MHC CLASS II DEFICIENCY}

The natural history of non-transplanted patients is dismal with a mean age of death at 4 years of age and the main cause of death is overwhelming viral infection (12). Very few children reach puberty and survive into adulthood (13). There are no clear differences in prognosis among patients harboring the four different genetic defects. Currently the only known cure for MHC class II deficiency is allogeneic hematopoietic cell transplantation (HCT). Historically this has only been reluctantly offered due to the high risk of transplant-related morbidity and mortality. Additionally, HCT for MHC class II deficiency is challenging as many children have significant comorbidities at the time of HCT. Transplant strategies to optimize the transplant survival of patients with MHC class II deficiency can be divided into three phrases: (1) pre-transplant phase; (2) transplant phase; and (3) post-transplant phase.

\section{PRE-TRANSPLANT PHASE}

As younger age at HSCT has been consistently shown to be associated with improved survival in children with primary immunodeficiency, HCT should be performed as early as possible before the onset of organ damage from multiple infections. Some patients with MHC class II deficiency can be detected used TREC-based newborn screening assays, and the diagnosis confirmed by looking for MHC class II expression (9-11). Once the diagnosis of MHC class II deficiency is suspected, a child should be referred promptly to an expert team for evaluation and confirmation of the diagnosis. The transplant process should be initiated and performed as soon as possible. Patients might require treatment of infections, respiratory supports and nutritional rehabilitation to optimize their organ function prior to HCT. A multidisciplinary team with participation of respiratory physicians, gastroenterologists, dietitians, play therapies and other supportive groups are required in all the phases in order to achieve the best outcome possible.

\section{TRANSPLANT PHASE}

This consists of donor selection, appropriate stem cell source and optimal conditioning regimen. As graft-vs. -host disease confers no benefit to patients with MHC class II deficiency, the best HLA-matched donor is a sibling or matched family donor. If no family donor is found, a search of the national or international
A

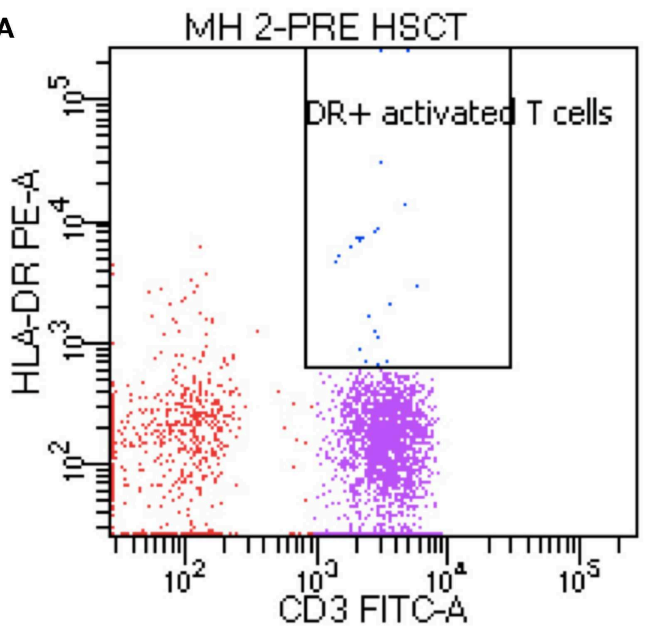

B

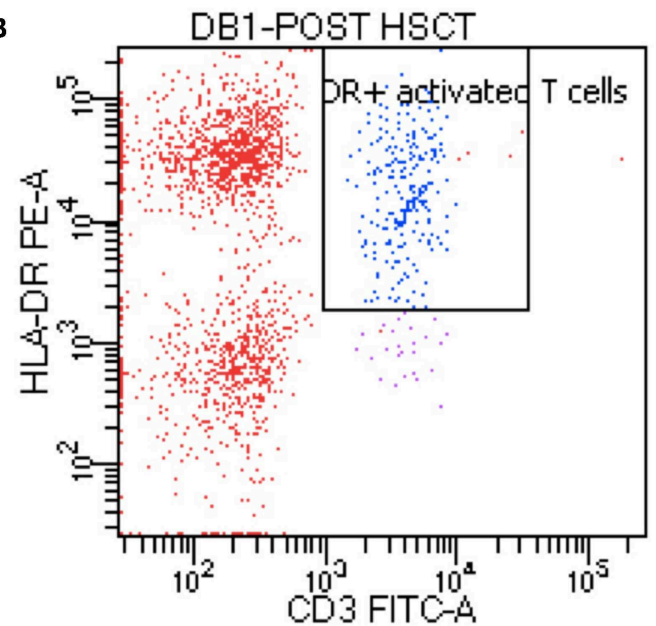

FIGURE 2 | Flow cytometry of a patient MHC class II deficiency. Pre-transplant (A) flow cytometry shows absence HLA-DR and post-transplant (B) flow cytometry shows presence of HLA-DR. 
TABLE 1 | Outcome of allogeneic hematopoietic cell transplantation for MHC class II deficiency.

\begin{tabular}{|c|c|c|c|c|c|c|c|c|c|c|}
\hline References & Year of HCT & $\begin{array}{l}\text { No. of } \\
\text { patients }\end{array}$ & $\begin{array}{l}\text { Median age } \\
\text { at HCT, } \\
\text { months } \\
\text { (range) }\end{array}$ & $\begin{array}{l}\text { Donor and stem } \\
\text { cell source }\end{array}$ & Conditioning regimen & $\begin{array}{l}\text { GvHD } \\
\text { prophylaxis }\end{array}$ & Stem cell doses & $\begin{array}{l}\text { Grade II-IV } \\
\text { aGvHD }\end{array}$ & cGvHD & OS (\%) \\
\hline $\begin{array}{l}\text { Elfeky et al. } \\
\text { (19) }\end{array}$ & NA & 6 & $25(12-38)$ & $\begin{array}{l}2 \text { 10/10 UCB } \\
4 \text { 9/10 UCB }\end{array}$ & $\begin{array}{l}\text { Flu } 150 \mathrm{mg} / \mathrm{m}^{2} \\
\text { Treo } 42 \mathrm{~g} / \mathrm{m}^{2} \\
\text { No serotherapy }\end{array}$ & $\mathrm{CSA}+\mathrm{MMF}$ & $\begin{array}{l}\text { Median CD34 } 2.1 \times \\
10^{5} / \mathrm{kg}\end{array}$ & $4(67 \%)$ & 2 & 100 \\
\hline $\begin{array}{l}\text { Small et al. } \\
\text { (15) }\end{array}$ & 1990-2013 & 16 & $12(6-48)$ & $\begin{array}{l}10 \text { MMFD } \\
4 \text { MUD } \\
2 \text { UCB } \\
5 \text { marrow } \\
2 \text { PBSC } \\
1 \text { TCD marrow } \\
6 \text { TCD PBSC }\end{array}$ & $\begin{array}{l}\frac{\text { TCD marrow/PBSC }}{\text { Bu } 16 \mathrm{mg} / \mathrm{kg}+\text { Flu }}+\text { Thiotepa or } \\
\text { Bu } 16 \mathrm{mg} / \mathrm{kg}+\text { Thiotepa + Cy } \\
\text { Bu } 16 \mathrm{mg} / \mathrm{kg}+\text { Flu + Cy } \\
\text { Bu } 16 \mathrm{~m} / \mathrm{kg}+\text { Cy } \\
\text { Unmodified marrow/PBSC } \\
\text { Bu + Flu + Cy or } \\
\text { Thiotepa + Cy or } \\
\text { Melphalan + Flu + anti-CD52 } \\
\text { Flu + Cy, anti-CD45 and anti-CD52 } \\
\text { or } \\
\text { Low dose Cy + Flu + 200cGy TBI } \\
\underline{\text { UCB }}\end{array}$ & $\mathrm{CSA}+\mathrm{MMF}$ & NA & $4(25 \%)$ & $\begin{array}{l}1 \text { post } \\
\text { 2nd HCT }\end{array}$ & 69 \\
\hline $\begin{array}{l}\text { Al-Mousa } \\
\text { et al. (17) }\end{array}$ & 1994-2007 & $\begin{array}{l}30 \\
\text { ( } 3 \text { had } \\
\text { second } \mathrm{HCT})\end{array}$ & $27(1-120)$ & $\begin{array}{l}26 \text { MFD marrow } \\
3 \text { MMFD marrow } \\
1 \cup C B\end{array}$ & $\begin{array}{l}\text { Bu } 16 \mathrm{mg} / \mathrm{kg}+\text { Cy } 200 \mathrm{mg} / \mathrm{kg}+ \\
\text { VP16 } 300 \mathrm{mg} / \mathrm{m}^{2} \text { or } \\
\text { Bu } 16 \mathrm{mg} / \mathrm{kg}+\text { Cy } 200 \mathrm{mg} / \mathrm{kg}+\text { ATG } \\
\text { Cy } 200 \mathrm{mg} / \mathrm{kg}+\text { TBI or } \\
\text { Flu } 150 \mathrm{mg} / \mathrm{m}^{2}+\text { melphalan } 140 \\
\mathrm{mg} / \mathrm{m}^{2}+\text { ATG }\end{array}$ & $\begin{array}{l}\text { CSA + MTX } \\
\text { or CSA or } \\
\text { CSA + } \\
\text { steroid }\end{array}$ & $\begin{array}{l}\text { Median CD34 } 8.3 \times \\
10^{6} / \mathrm{kg}(3-20.7 \times \\
\left.10^{6} / \mathrm{kg}\right)\end{array}$ & $\begin{array}{l}\frac{\text { MAC }}{9 \text { grade II-III skin }} \\
\text { aGvHD } \\
5 \text { grade II-III gut } \\
\text { aGvHD } \\
1 \text { lung GvHD } \\
\frac{\text { RIC }}{7 \text { grade } I-\| \text { aGvHD }}\end{array}$ & 3 & 66 \\
\hline $\begin{array}{l}\text { Siepermann } \\
\text { et al. (20) }\end{array}$ & NA & 1 & 18 & $7 / 10$ UCB & $\begin{array}{l}\text { Bu } 20 \text { mg/kg + Flu } 160 \mathrm{mg} / \mathrm{m}^{2}+\text { Cy } \\
120 \mathrm{mg} / \mathrm{kg}+\text { ATG }\end{array}$ & CSA & TNC $9 \times 10^{7} / \mathrm{Kg}$ & Grade I aGvHD & No & Alive \\
\hline $\begin{array}{l}\text { Renella et al. } \\
\text { (21) }\end{array}$ & $1981-2004$ & $\begin{array}{l}15 \\
\text { ( } 2 \text { had } \\
\text { second } \mathrm{HCT} \text { ) }\end{array}$ & $18(4-65)$ & $\begin{array}{l}13 \text { MFD marrow } \\
2 \text { MUD marrow } \\
\text { All } 2 \text { second HCT } \\
\text { used MSD }\end{array}$ & $\begin{array}{l}\text { Bu 16-20 mg/kg + Cy } 200 \mathrm{mg} / \mathrm{kg} \\
+ \text { ATG in MUD }\end{array}$ & $\mathrm{CSA}+\mathrm{MTX}$ & $\begin{array}{l}\text { Median TNC: } 4.3 \times \\
10^{9} / \mathrm{kg}\left(3.3 \times 10^{8} / \mathrm{kg}\right. \\
\left.\text { to } 5.5 \times 10^{9} / \mathrm{kg}\right)\end{array}$ & $7(47)$ & 2 & 53 \\
\hline $\begin{array}{l}\text { Saleem et al. } \\
\text { (3) }\end{array}$ & $1991-1999$ & $\begin{array}{l}6 \\
(2 \text { had } \\
\text { second HCT) }\end{array}$ & $\begin{array}{l}6.5(1-15.6 \\
\text { years })\end{array}$ & $\begin{array}{l}5 \mathrm{MFD} \\
1 \mathrm{MUD}\end{array}$ & $\begin{array}{l}\text { Bu } 16-20 \mathrm{mg} / \mathrm{kg}+\text { Cy } 200 \mathrm{mg} / \mathrm{kg} \pm \\
\text { Alemtuzumab } \pm \text { ATG } \pm \\
\text { anti-LFA-1/CD2 or Flu }+ \text { Melphalan }\end{array}$ & CSA & $\begin{array}{l}\text { Median TNC: } 5.9 \times \\
10^{8} / \mathrm{kg}\left(1-11.510^{8} / \mathrm{kg}\right)\end{array}$ & NA & NA & 33 \\
\hline $\begin{array}{l}\text { Godthelp } \\
\text { et al. (22) }\end{array}$ & 1993-1995 & 2 & 8,23 & 2 MFD marrow & Bu 20 mg/kg + Cy 200 mg/kg & CSA + MTX & TNC $2.5-4.6 \times 10^{8} / \mathrm{kg}$ & None & None & Both alive \\
\hline $\begin{array}{l}\text { Bonduel et al. } \\
\text { (23) }\end{array}$ & 1994 & $\begin{array}{l}1 \\
\text { (had } 2 \mathrm{HCT})\end{array}$ & 22 & $\begin{array}{l}\text { MMUD TCD } \\
\text { marrow }\end{array}$ & $\begin{array}{l}\text { Bu } 20 \mathrm{mg} / \mathrm{kg}+\text { Cy } 200 \mathrm{mg} / \mathrm{kg}+ \\
\text { anti-LFA1 + anti-CD2 }\end{array}$ & CSA & TNC $0.2 \times 10^{8} / \mathrm{kg}$ & Grade II GvHD & None & $\begin{array}{l}\text { Alive after } \\
\text { second } \\
\text { sibling CBT }\end{array}$ \\
\hline
\end{tabular}




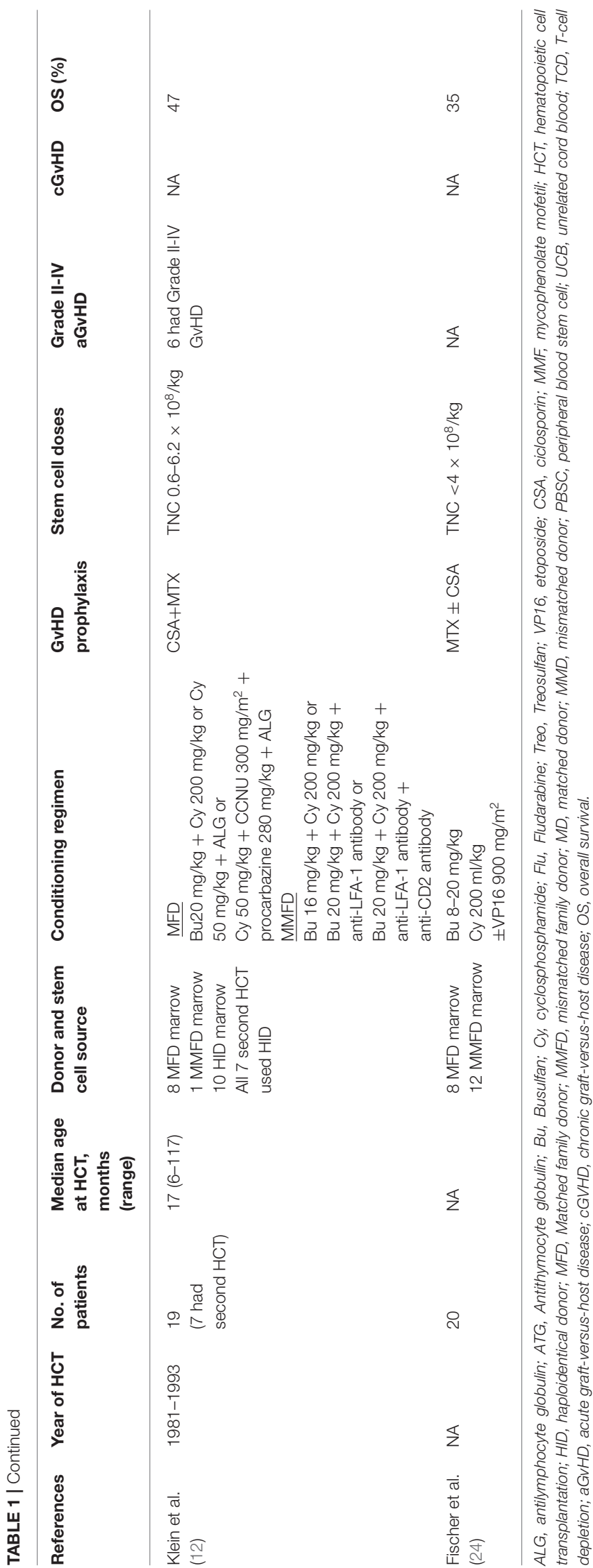

unrelated donor registries should be undertaken. Parental haploidentical donors with newer methods of T-lymphocyte depletion have emerged as promising alternative donors while classic haploidentical HSCT with CD34+ selection have shown high rate of non-engraftment in historical series (13-16).

The use of myeloablative reduced-toxicity conditioning (RTC) is preferred in children with MHC class II deficiency as many patients have multiple chronic infections and organ damage at the time of HCT. RTC reduces early transplant complications and late effects such as infertility. In addition, full donor chimerism is not mandatory since stable mixed chimerism on lymphoid and myeloid compartments have been reported to achieve long-term cures. Experiences with reduced intensity conditioning (RIC) are limited. Al-Mousa et al. reported 12 patients transplanted mainly with intra-familial geno-identical donor after a RIC (flu-mel and ATG) and reported mixed lymphoid and myeloid chimerism in all patients but sufficient to cure the disease (17). Outside a geno-identical donor, RIC needs to be used with caution. Based on the current evidence, the European Society for Blood and Marrow Transplant developed a guideline for patients with primary immunodeficiencies (PID) (18). Bone marrow has been the conventional source of stem cells but peripheral blood stem cells have been increasingly used together with RTC to improve donor chimerism (19).

\section{POST-TRANSPLANT PHASE}

In this phase, the main tasks are monitoring of donor graft, surveillance of transplant-related complications and rehabilitation of pre-transplant organ damage.

\section{OUTCOME AND IMMUNE RECONSTITUTION AFTER HAEMATOPOIETIC CELL TRANSPLANTATION IN CHILDREN WITH MHC CLASS II DEFICIENCY}

More than 100 transplants have been reported worldwide (Table 1) (3, 14, 15, 17, 20, 21, 23-26). Patients with MHC class II deficiency are difficult to transplant with increased regimen-related toxicities, serious infections, graft rejection, and GvHD. The conditioning protocols used in these patients were variable and the majority of patients were conditioned with Busulfan-based myeloablative conditioning. In the early reports, the transplant survival was poor compared to those seen in patients with other PIDs, with a survival rate of $50 \%$ or less (3, 14, 21, 23, 24). Recently, a better transplant outcome has been reported, the overall survival ranges $66-100 \%$ and reduced toxicity conditioning has been increasingly used in these reports. $(15,17,26)$. A high incidence of acute graft-versus-host disease has been reported in these patients and this can be accounted by lack of in-vivo T-lymphocyte depletion with serotherapy. High rate of chronic persistent viral infections before transplantation may also increase the risk of GVHD. Patients undergoing HCT before 2 years of age had better prognosis (14). 
Among HSCT long-term survivors, persistent CD4+ Tlymphocytopenia has been observed in post-HCT patients. This observation can ben explained by impaired thymic maturation resulting from defective $\mathrm{MHC}$ class II expression on thymic epithelia. Although the CD4+ T-lymphocyte number is low, transplanted patients show normalization of antigen-specific Tlymphocyte stimulation and antibody production in response to vaccination. Partial engraftment post-HCT has been associated with impaired immune repertoire (22).

\section{SUMMARY}

MHC class II deficiency is rare but invariably fatal primary immunodeficiency. Allogenic HCT is the only curative treatment and is considered the treatment of choice. Pre-transplant

\section{REFERENCES}

1. Lisowska-Grospierre B, Durandy A, Virelizier JL, Fischer A, Griscelli C. Combined immunodeficiency with defective expression of HLA: modulation of an abnormal HLA synthesis and functional studies. Birth Defects Orig Artic Ser. (1983) 19:87-91.

2. Mach B, Steimle V, Martinez-Soria E, Reith W. Regulation of MHC class II genes: lessons from a disease. Annu Rev Immunol. (1996) 14:301-31. doi: 10.1146/annurev.immunol.14.1.301

3. Saleem MA, Arkwright PD, Davies EG, Cant AJ, Veys PA. Clinical course of patients with major histocompatibility complex class II deficiency. Arch Dis Child. (2000) 83:356-9. doi: 10.1136/adc.83.4.356

4. Rozmus J, Junker A, Thibodeau ML, Grenier D, Turvey SE, Yacoub W, et al. Severe combined immunodeficiency (SCID) in Canadian children: a national surveillance study. J Clin Immunol. (2013) 33:1310-6. doi: 10.1007/s10875-013-9952-8

5. Al-Herz W, Alsmadi O, Melhem M, Recher M, Frugoni F, Notarangelo LD. Major histocompatibility complex class II deficiency in Kuwait: clinical manifestations, immunological findings and molecular profile. J Clin Immunol. (2013) 33:513-9. doi: 10.1007/s10875-0129831-8

6. Reith W, LeibundGut-Landmann S, Waldburger JM. Regulation of MHC class II gene expression by the class II transactivator. Nat Rev Immunol. (2005) 5:793-806. doi: 10.1038/nri1708

7. Picard C, Bobby Gaspar H, Al-Herz W, Bousfiha A, Casanova JL, Chatila $\mathrm{T}$, et al. International union of immunological societies: 2017 primary immunodeficiency diseases committee report on inborn errors of immunity. J Clin Immunol. (2018) 38:96-128. doi: 10.1007/s10875-0170464-9

8. Hanna S, Etzioni A. MHC class I and II deficiencies. J Allergy Clin Immunol. (2014) 134:269-75. doi: 10.1016/j.jaci.2014.06.001

9. Lev A, Simon AJ, Broides A, Levi J, Garty BZ, Rosenthal E, et al. Thymic function in MHC class II-deficient patients. J Allergy Clin Immunol. (2013) 131:831-9. doi: 10.1016/j.jaci.2012.10.040

10. Marcus N, Stauber T, Lev A, Simon AJ, Stein J, Broides A, et al. MHC II deficient infant identified by newborn screening program for SCID. Immunol Res. (2018) 66:537-42. doi: 10.1007/s12026-018-9019-2

11. Aluri J, Gupta M, Dalvi A, Mhatre S, Kulkarni M, Hule G, et al. Clinical, immunological, and molecular findings in five patients with major histocompatibility complex class II deficiency from India. Front Immunol. (2018) 9:188. doi: 10.3389/fimmu.2018.00188

12. Klein C, Lisowska-Grospierre B, LeDeist F, Fischer A, Griscelli C. Major histocompatibility complex class II deficiency: clinical manifestations, immunologic features, and outcome. J Pediatr. (1993) 123:921-8. doi: 10.1016/S0022-3476(05)80388-9

13. Ouederni M, Vincent QB, Frange P, Touzot F, Scerra S, Bejaoui M, et al. Major histocompatibility complex class II expression deficiency caused by a treatment of infections and optimization of nutritional status and organ function are important to improve transplant survival. Transplant survival has improved with reduced toxicity conditioning regimen, better donor availability, improved supportive care, and more effective anti-microbial therapy. There is a need for a multi-center study to delineate the predictors of outcome of HCT in MHC class II deficiency in the modern era of HCT. Advances in gene therapy may be attractive as a potential therapeutic alternative for children with MHC class II deficiency $(27,28)$.

\section{AUTHOR CONTRIBUTIONS}

SL performed the literature review and prepared the manuscript. MS, BN, and AG critically reviewed the manuscript.

RFXANK founder mutation: a survey of 35 patients. Blood. (2011) 118:510818. doi: 10.1182/blood-2011-05-352716

14. Klein C, Cavazzana-Calvo M, Le Deist F, Jabado N, Benkerrou M, Blanche $\mathrm{S}$, et al. Bone marrow transplantation in major histocompatibility complex class II deficiency: a single-center study of 19 patients. Blood. (1995) 85:580-7. doi: 10.1182/blood.V85.2.580.580

15. Small TN, Qasim W, Friedrich W, Chiesa R, Bleesing JJ, Scurlock A, et al. Alternative donor SCT for the treatment of MHC class II deficiency. Bone Marrow Transplant. (2013) 48:226-32. doi: 10.1038/bmt. 2012.140

16. Shah RM, Elfeky R, Nademi Z, Qasim W, Amrolia P, Chiesa R, et al. T-cell receptor alphabeta $(+)$ and $\mathrm{CD} 19(+)$ cell-depleted haploidentical and mismatched hematopoietic stem cell transplantation in primary immune deficiency. J Allergy Clin Immunol. (2018) 141:1417-26.e1. doi: $10.1016 /$ j.jaci.2017.07.008

17. Al-Mousa H, Al-Shammari Z, Al-Ghonaium A, Al-Dhekri H, Al-Muhsen S, Al-Saud B, et al. Allogeneic stem cell transplantation using myeloablative and reduced-intensity conditioning in patients with major histocompatibility complex class II deficiency. Biol Blood Marrow Transplant. (2010) 16:818-23. doi: 10.1016/j.bbmt.2010.01.002

18. Effros RB, Dillard L, Zeller E, Naeim F, Walford RL. Strong HLA$\mathrm{DR}$ expression in $\mathrm{T}$ cell cultures after activation is necessary for IL-2-dependent proliferation. Hum Immunol. (1983) 8:249-54. doi: 10.1016/0198-8859(83)90051-4

19. Slatter MA, Rao K, Abd Hamid IJ, Nademi Z, Chiesa R, Elfeky R, et al. Treosulfan and fludarabine conditioning for hematopoietic stem cell transplantation in children with primary immunodeficiency: UK experience. Biol Blood Marrow Transplant. (2018) 24:529-36. doi: 10.1016/j.bbmt.2017.11.009

20. Siepermann M, Gudowius S, Beltz K, Strier U, Feyen O, Troeger A, et al. MHC class II deficiency cured by unrelated mismatched umbilical cord blood transplantation: case report and review of 68 cases in the literature. Pediatr Transplant. (2011) 15:E80-6. doi: 10.1111/j.1399-3046.2010. 01292.x

21. Renella R, Picard C, Neven B, Ouachee-Chardin M, Casanova JL, Le Deist F, et al. Human leucocyte antigen-identical hematopoietic stem cell transplantation in major histocompatiblity complex class II immunodeficiency: reduced survival correlates with an increased incidence of acute graft-versus-host disease and pre-existing viral infections. Br J Haematol. (2006) 134:510-6. doi: 10.1111/j.1365-2141.2006. 06213.x

22. Godthelp BC, van Eggermond MC, Peijnenburg A, Tezcan I, van Lierde $\mathrm{S}$, van Tol $\mathrm{MJ}$, et al. Incomplete $\mathrm{T}$-cell immune reconstitution in two major histocompatibility complex class II-deficiency/bare lymphocyte syndrome patients after HLA-identical sibling bone marrow transplantation. Blood. (1999) 94:348-58. doi: 10.1182/blood.V94.1.348.413k05_ $348 \quad 358$ 
23. Bonduel M, Pozo A, Zelazko M, Raslawski E, Delfino S, Rossi J, et al. Successful related umbilical cord blood transplantation for graft failure following $\mathrm{T}$ celldepleted non-identical bone marrow transplantation in a child with major histocompatibility complex class II deficiency. Bone Marrow Transplant. (1999) 24:437-40. doi: 10.1038/sj.bmt.1701915

24. Fischer A, Landais P, Friedrich W, Gerritsen B, Fasth A, Porta F, et al. Bone marrow transplantation (BMT) in Europe for primary immunodeficiencies other than severe combined immunodeficiency: a report from the European Group for BMT and the European Group for Immunodeficiency. Blood. (1994) 83:1149-54. doi: 10.1182/blood.V83.4.1149.1149

25. Godthelp BC, Van Eggermond MC, Van Tol MJ, Vossen JM, van den Elsen PJ. T cell immune reconstitution after allogeneic bone marrow transplantation in bare lymphocyte syndrome. Hum Immunol. (2000) 61:898907. doi: 10.1016/S0198-8859(00)00156-7

26. Elfeky R, Furtado-Silva JM, Chiesa R, Rao K, Lucchini G, Amrolia P, et al. Umbilical cord blood transplantation without in vivo T-cell depletion for children with MHC class II deficiency. J Allergy Clin Immunol. (2018) 141:2279-82 e2. doi: 10.1016/j.jaci.2017.10.051
27. Matheux F, Villard J. Cellular and gene therapy for major histocompatibility complex class II deficiency. News Physiol Sci. (2004) 19:154-8. doi: 10.1152/nips.01462.2003

28. Booth C, Gaspar HB, Thrasher AJ. Treating immunodeficiency through HSC gene therapy. Trends Mol Med. (2016) 22:317-27. doi: 10.1016/j.molmed.2016.02.002

Conflict of Interest: The authors declare that the research was conducted in the absence of any commercial or financial relationships that could be construed as a potential conflict of interest.

Copyright (c) 2019 Lum, Neven, Slatter and Gennery. This is an open-access article distributed under the terms of the Creative Commons Attribution License (CC BY). The use, distribution or reproduction in other forums is permitted, provided the original author(s) and the copyright owner(s) are credited and that the original publication in this journal is cited, in accordance with accepted academic practice. No use, distribution or reproduction is permitted which does not comply with these terms. 